УДК 342

DOI https://doi.org/10.32837/pyuv.v0i1(30).526

\author{
В. І. Мельник \\ orcid.org/0000-0003-3800-7462 \\ докторант кафедри адміністративного, господарського права та фінансово-економічної безпеки \\ Сумського державного університету
}

\title{
СТРУКТУРА ТА ОСОБЛИВОСТІ ПРАВОВОГО ЗАБЕЗПЕЧЕННЯ ФУНКЦІОНУВАННЯ СИСТЕМИ ЕКОНОМІЧНОЇ БЕЗПЕКИ УКРАЇНИ ${ }^{1}$
}

Постановка проблеми. Система економічної безпеки України, зважаючи на її складність і багатогранність, порівняно з більшістю інших безпекових складників має як пряме, так і опосередковане відношення до широкого кола правовідносин, врегульованих положеннями значної кількості правових актів різної юридичної сили. Вказані документи, будучи продуктом нормотворчого процесу з боку компетентних державних інституцій, формують правове підгрунтя для функціонування досліджуваної системи та відображають волю держави в питанні її подальшого розвитку.

Враховуючи цю обставину, доцільно приділити увагу питанням виокремлення та структуризації тих актів, положення яких мають суттєве значення для правового забезпечення функціонування системи економічної безпеки України. В наукових джерелах в такому контексті зазвичай обмежуються профільними безпековими законодавчими та підзаконними нормативно-правовими актами, залишаючи поза увагою низку інших вагомих юридичних документів.

Мета дослідження - усвідомлюючи багатогранність системи економічної безпеки України, запропонувати власне бачення груп ключових нормативно-правових документів, які є основою для функціонування останньої.

Виклад основного матеріалу. В сучасній науковій літературі міститься багато думок стосовно виокремлення актів, які слугують правовою основою для функціонування економічного складника державної безпеки, рівнів, а також критеріїв їх диференціації. Наприклад, К.О. Утенкова виокремлює шість рівнів правового врегулювання економічної безпеки держави: 1) Конституція України; 2) кодифіковані збірники нормативно-правових актів; 3) базовий закон; 4) закони 3 питань безпеки чи діяльності суб'єктів забезпечення економічної безпеки; 5) підзаконні нормативні документами; 6) нормативні акти органів місцевого самоврядування, суб'єктів господарювання тощо [1, с. 133-134].

На думку автора, за такого підходу не буде охоплено широке коло законодавчих актів з питань забезпечення функціонування економічного складника (зовнішньоекономічна діяльність, банкрутство, приватизація). Також відсутні згадки про міжнародні й міждержавні акти, учасником яких є українська сторона, адже їх положення мають важливе значення під час реалізації державної безпекової політики. Дискусійним є питання щодо ролі актів суб'єктів господарювання з позиції їх дійсної значимості та можливого впливу на процес правового забезпечення функціонування економічної безпеки України.

На думку автора, для виділення та систематизації основних актів варто брати до уваги деякі положення Кримінального кодексу України від 05.04.2001 р. № 2341-III, нормами якого охороняється широке коло відносин в економічній сфері. Насамперед це стосується діянь, які в науковій літературі часто називають «економічними злочинами», під якими варто розуміти передбачені чинним кримінальним законодавством суспільно-небезпечні винні діяння, внаслідок здійснення яких знижується або виникає ризик зниження рівня ефективності функціонування національної економіки та втрачається ії здатність до сталого та збалансованого зростання [2, с. 178,3 , с. 249].

Зважаючи на ту суттєву обставину, що до групи так званих «економічних злочинів» у наукових колах прийнято відносити широкий перелік протиправних діянь (А.Л. Дудніков [4], В.В. Коваленко [5, с. 29-30], В.І. Франчук [6, с. 123-124], C.С. Чернявський $[7$, с. 87]), то варто зупинитися на окремих із їх числа, ймовірні наслідки від скоєння яких негативно впливатимуть на вітчизняну економіку. Серед цих протиправних діянь, усвідомлюючи їх значимість та оцінюючи потенційні ризики для національної економіки, доцільно окремо виділити групу відносин, яким присвячений Розділ VII «Злочини в сфері господарської діяльності» Кримінального кодексу України від 05.04.2001 р. № 2341-III.

3 числа таких відносин, на переконання Ю.В. Гаруста й І.В. Скорохода, варто виокремити ті, які виникають та існують у сферах: 1) кредитно-посередницької і банківської діяльності; 2) зовнішньоекономічної діяльності; 3) підприємницької діяльності; 4) приватизації; 5) державних

${ }^{1}$ Робота виконана в проєкті 0118U003582. 
фінансів; 6) споживчого кредиту [8, с. 12; 9, с. 13]. Не виникає сумніву, що в результаті скоєння вказаних правопорушень існує висока вірогідність появи та посилення негативного впливу на національну економіку. 3 огляду на це основні нормативно-правові акти, положеннями яких регулюються відносини в цих сферах, є важливою групою джерел для функціонування системи економічної безпеки України.

На основі викладеного пропонується така градація нормативно-правових актів із забезпечення функціонування економічної безпеки України: 1) Конституція України; 2) міжнародні, міждержавні конвенції, угоди та договори; 3) базовий закон; 4) інші закони, норми яких прямо чи опосередковано стосуються питань економічної безпеки у сферах: 1) кредитно-посередницької і банківської діяльності; 2) зовнішньоекономічної діяльності; 3) підприємницької діяльності; 4)мприватизації; 5) державних фінансів; 6) споживчого кредиту; 7) інших сферах; 5) закони, які окреслюють правовий статус суб'єктів із забезпечення економічної безпеки України; 6) кодифіковані нормативно-правові акти; 7) підзаконні нормативно-правові акти, які варто поділити на дві групи: а) ті, що окреслюють правовий статус суб'єктів із забезпечення економічної безпеки України; б) пов'язані з забезпеченням функціонування економічної безпеки України та сприяють її розвитку.

Щодо Основного Закону України автор погоджується 3 думкою С.I. Лекаря, який стверджує, що в Конституції України чітко зазначено, що поряд із захистом суверенітету і територіальної цілісності України забезпечення ії̈ економічної та інформаційної безпеки є найважливішими функціями держави, справою всього українського народу (ст. 17). [10, с. 71-72]. Цей документ закладає основи для здійснення захисту економічного складника державної безпеки. Також ним встановлено пріоритетні ціннісні орієнтири держави 3 діяльності щодо забезпечення системи економічної безпеки України.

Щодо наступного рівня, то варто згадати Заключний акт Наради з безпеки і співпраці в Європі від 01.08.1975 р., відповідно до якого однією 3 ключових засад визнається не перешкоджання економічному розвитку держав.

Доцільно до цієї групи віднести й багатосторонні договори 3 іншими державами (Європейська конвенція про видачу правопорушників від 13.12.1957р.), двосторонні договори України 3 іншими державами у сфері надання взаємної допомоги (Договір між Україною та Канадою про взаємодопомогу у кримінальних справах від 23.09.1996 р.), міжвідомчі угоди (Про правову допомогу і співробітництво між Генеральною прокуратурою України і Генеральною прокуратурою Литовської Республіки від 08.12.1992р.) тощо. Також у межах цієї групи джерел окремо слід виділити Угоду про асоціацію між Україною та Європейським Союзом, Європейським співтовариством з атомної енергії і їхніми державами-членами від 27.06.2014 p., якою закладаються та визнаються нові вектори розвитку української держави. Низка положень цього документу присвячена й економічному компоненту («Торгівля й питання, пов'язані з торгівлею», «Економічне і галузеве співробітництво»).

Особливе значення в існуючій системі джерел правового забезпечення функціонування системи економічної безпеки України відіграє базовий законодавчий акт - ЗУ «Про національну безпеку» від 21.06.2018 р. № 2469-VIII. Вказаним документом визначено основи та принципи національної безпеки й оборони, цілі та основні засади державної політики, які гарантуватимуть суспільству і кожному громадянину захист від загроз.

Наступною важливою групою є законодавчі акти, норми яких стосуються питань системи економічної безпеки України. Це насамперед стосується відносин у сферах: 1) кредитно-посередницької і банківської діяльності (ЗУ «Про банки і банківську діяльність» від 07.12.2000 p. № 2121-III); 2) зовнішньоекономічної діяльності (ЗУ «Про зовнішньоекономічну діяльність» від 16.04.1991 p. № 959-XII); 3) підприємницької діяльності (ЗУ «Про електронну комерцію» від 03.09.2015 р. № 675-VIII); 4) приватизації (ЗУ «Про управління об'єктами державної власності» від 21.09.2006 p. № 185-V); 5) державних фінансів (ЗУ «Про систему гарантування вкладів фізичних осіб» від 23.02.2012 р. № 4452-VI); $6)$ споживчого кредиту (ЗУ «Про іпотечне кредитування, операції з консолідованим іпотечним боргом та іпотечні сертифікати» від 19.06.2003 p. № 979-IV); 7) інших сферах (ЗУ «Про запобігання та протидію легалізації (відмиванню) доходів, одержаних злочинним шляхом, фінансуванню тероризму та фінансуванню розповсюдження зброї масового знищення» від 14.10.2014 р. № 1702-VII).

Наступною групою є закони, які регламентують діяльність суб'єктів із забезпечення системи економічної безпеки України. Положеннями таких нормативно-правових актів визначено завдання, функції, окреслено права та обов'язки, а також регламентовано інші складники правового статусу відповідної структури саме як суб'єкта забезпечення економічної безпеки держави (ЗУ «Про прокуратуру» від 14.10.2014 р. № 1697-VII). Деякі аспекти, які стосуються питань правових засад щодо забезпечення економічної безпеки України, висвітлені у кодифікованих актах (Господарський кодекс України від 16.01.2003 р. № 436-IV тощо).

3 приводу підзаконних нормативно-правових актів, то цій групі джерел також відводиться вагоме місце. На переконання В.Л. Ортинського, ці 
акти в сфері економічної безпеки мають певні особливості: 1) конкретизують багато принципових положень законів, забезпечуючи максимальну реалізацію законних інтересів у сфері економіки особи, юридичних осіб і суспільства; 2) у випадках відсутності законодавчого регулювання підзаконні акти в сфері економічної безпеки регулюють суспільні відносини, закріплені за органом, який видає такий вид актів, замість закону; 3) підзаконні акти у сфері економічної безпеки відрізняються різноманітністю та неоднорідністю, однак через відсутність юридичного закріплення системи нормативних актів часто досить важко визначити їхню ієрархію та юридичну силу відповідних документів; 4) підзаконні акти в сфері економічної безпеки мають державний характер, оскільки реалізація ухвалених нормативно-правових актів, зокрема і примусовий вплив на осіб, які ухиляються від їх виконання, є обов'язком державних органів; 5) зазначені акти приймають відповідно до встановленої іншими нормативними актами процедури і з урахуванням вимог до змісту та форми [11, с. 7]. Тобто, науковець вкотре підтверджує запропоновану точку зору, що для системи економічної безпеки є характерним специфічне правове забезпечення.

3 приводу цих актів, то умовно автор виділяе дві групи вказаних документів: 1) ті, які окреслюють правовий статус суб'єктів із забезпечення економічної безпеки України (Положення про Міністерство фінансів України від 20.08.2014 р. № 375); 2) пов’язані із забезпеченням функціонування економічної безпеки України та які сприяють їі розвитку (Стратегія національної безпеки України від 26.05.2015 р. № 287/2015). Для системи економічної безпеки України, зважаючи на iї складність і багатогранність, характерним $\epsilon$ iснування значної кількості правових актів різної юридичної сили, які формують правове підгрунтя для функціонування й встановлюють вектори розвитку останньої. Кожному з таких документів відводиться власна роль у цьому процесі залежно від ступеня впливу й сфер охоплення.

Висновки. За результатами дослідження запропоновано власне бачення груп і систематизовано ключові нормативно-правові документи, які слугують основою для функціонування системи економічної безпеки України. Вказаними актами охоплено широке коло відносин у межах економічного складника державної безпеки.

\section{Jimepamypa}

1. Утенкова К.О. Економічна безпека як складник національної безпеки України. Вісник Харківського національного університету імені В.Н. Каразіна. Сeрія: Міжнародні відносини. Економіка. Країнознавство. Туризм, 2019. Вип. 9. С. 133-144.

2. Гаруст Ю.В., Мельник В.І. Правоохоронні органи на захисті економічної безпеки України: адміністра- тивно-правовий аспект : монографія. Суми : Видавничо-виробниче підприємство «Мрія», 2019. $256 \mathrm{c}$.

3. Harust Yu., Melnyk V., Kiiashko Yu., Halunko V. Economic crimes: Innovative mechanisms of counteraction by law enforcement agencies. Asia Life Sciences, 2019 (2), P. 247-263.

4. Дудніков А.Л. Поняття та система злочинів у сфері економіки. Сучасні проблеми криміналістики. Вип. 7. URL: http://dspace.nlu.edu.ua/ bitstream/123456789/13063/1/Dudnikov 25-31.pdf (дата звернення: 15.04.2020).

5. Коваленко В.В. Організація профілактики економічної злочинності в Україні : дис. д-ра юрид. наук: 12.00.07. Харків, 2004. 398 с.

6. Франчук В.I., Герасименко Л.В., Гончарова В.О. та інші. Економічна безпека : навчальний посібник. Львів : ЛьвДУВС, 2010. 244 с.

7. Чернявський С.С. Фінансове шахрайство: методологічні засади розслідування : монографія. Київ : Хай-Тек Прес, 2010. 624 с.

8. Гаруст Ю.В., Скороход І.В. Злочини у сфері господарської діяльності : підручник. Суми : видавництво «Ярославна», 2017. 348 с.

9. Гаруст Ю.В., Скороход І.В. Злочини у сфері господарської діяльності : підручник. Суми : Сумський державний університет, 2017. 1056 с.

10. Лекарь C.I. Нормативно-правове забезпечення діяльності органів державної влади як суб'єктів економічної безпеки. Право і безпека, 2012. № 4 (46). C. $70-75$.

11. Ортинський В.Л. Аналіз нормативно-правової основи забезпечення економічної безпеки. Вісник $\mathrm{Ha}$ иіонального університету «Львівська політехніка». Юридичні науки, 2016. № 855. С. 4-12.

\section{Анотація}

Мельник В. I. Структура та особливості правового забезпечення функціонування системи економічної безпеки України. - Стаття.

Стаття присвячена питанню визначення та аналізу структури, а також з'ясуванню особливостей правового забезпечення системи економічної безпеки України. Наголошено, що система економічної безпеки держави як багатогранне та складне явище має як пряме, так і опосередковане відношення до широкого кола сфер правовідносин, врегульованих положеннями відповідних актів.

Акцентовано увагу на важливості таких документів як основного способу вираження волі держави з метою виправданого, необхідного, а також легітимного впливу інституцій останньої на поведінку учасників тих чи інших правовідносин. Зазначено та обгрунтовано, що ці акти, прийняті (затверджені) за попередньо встановленою процедурою і розраховані на багаторазове застосування, змінюють або скасовують відповідні правові норми, окреслюють компетенцію суб'єктів забезпечення системи економічної безпеки України. Проаналізовано поширені підходи до структури цих документів саме в аспекті правового регулювання економічної безпеки держави. На основі одного з таких документів запропоновано авторську класифікації цих актів, які відграють ключову роль у питанні правового забезпечення системи економічної безпеки України.

Звернено увагу на відповідні положення Конституції України - головного документу в існуючій ієрархії нормативно-правових безпекових актів. Розглянуто ЗУ «Про національну безпеку» - ключовий документ, яким визначено основи та принципи національної безпеки, цілі й основні засади державної політики, які 
мають гарантувати захист від загроз, в тому числі й економічного характеру, а також досліджене інше безпекове законодавство.

Сфокусовано увагу на деяких аспектах актів, які регулюють відносини у сферах зовнішньоекономічної діяльності, банкрутства, приватизації й інших суміжних напрямів. Окрема роль відведена кодифікованим нормативно-правовим актам, нормам i принципам міжнародного права, а також підзаконним нормативно-правовим документам.

Ключові слова: акт, безпека, нормативно-правовий акт, правове забезпечення, система економічної безпеки України.

\section{Summary}

Melnyk V. I. Structure and features of legal support functioning of the economic security system of Ukraine. - Article.

The article is devoted to the issue of defining and analyzing the structure and finding out features of legal support of the economic security system of Ukraine. It is emphasized that the system of economic security of the state, as a complex phenomenon, naturally has both a direct and indirect relation to a wide range of legal spheres governed by the provisions of the respective acts.

Once again, attention is paid to the importance of such documents as the main way of expressing the will of the state for the justified, necessary and legitimate influence of the institutions of the latter on the behavior of participants of certain legal relationships. It is indicated and substantiated that these acts adopted (approved) under the predefined procedure and calculated on multiple use, or refer to the relevant legal norms, outline the subjects competence of the system of economic security of Ukraine, etc.

The common approaches to the structure of these documents are prevalent in the aspect of legal regulation of the economic security of the state. On the one basis of the following, the author's classification of these acts, which is played by a key role in the legal support issue of the economic security system of the Ukrainian state. The attention of the relevant provisions of the Constitution of Ukraine is the main document in the existing hierarchy of regulatory and legal security acts. Considered by the Law on National Security - a key document that defines the basics and principles of national security, the goals and main principles of state policy, which should guarantee protection against threats, including economic nature, as well as other relevant security legislation.

Attention is focused on some acts that regulate relations in the fields of foreign economic activity, bankruptcy, privatization and other related areas. A separate role is assigned to the codified normative legal acts, norms and principles of international law, as well as to the subordinate regulatory legal documents.

Key words: act, security, legal act, legal support, the economic security system of Ukraine. 